\title{
Rational use of blood: how to do it?
}

Helio Moraes-Souza ${ }^{1,2}$

'Universidade Federal do Triângulo Mineiro UFTM, Uberaba, MG, Brazil

${ }^{2}$ Fundação Centro de Hematologia

e Hemoterapia de Minas Gerais -

HEMOMINAS, Belo Horizonte, MG, Brazil
Conflict-of-interest disclosure:

The author declares no competing financial interest

Submitted: 7/30/2013

Accepted: 8/2/2013

Corresponding author

Helio Moraes de Souza

Fundação Centro de Hematologia e

Hemoterapia de Minas Gerais - Fundação

Hemominas

Alameda Ezequiel Dias, 321 - Bairro Santa Efigênia

30.130-110 Belo Horizonte, MG, Brazil

helio.moraes@dcm.uftm.edu.br
Transfusion medicine is a complex process that depends on several professionals. To do it safely, each professional depends not only on their own knowledge and skills, but also the knowledge and skills of the entire team and the efficiency of the system.

There is growing recognition of adverse events associated with blood transfusions and several factors may contribute to increase the chances of a patient suffering transfusionrelated complications. These factors include the type of component being transfused, the characteristics and clinical conditions of the patient, the use of inadequate equipment, inconsistent intravenous solutions, inadequate procedures and errors or omissions on the part of the team that provides care to the patient (clerical errors), in particular, in the identification of the patient and blood samples ${ }^{(1)}$.

With the goal of increasing the safety of blood transfusions, the majority of countries have specific legislation regulating transfusion medicine in their countries and regions covered. The RDC 57/ANVISA ${ }^{(2)}$ and Ordinance 1353/MS ${ }^{(3)}$ in Brazil, the British red blood cell transfusion guidelines in the United Kingdom ${ }^{(4)}$, the Council of Europe Resolutions, recommendations and Convention in the Common Market ${ }^{(5)}$ and the Blood Transfusion Safety of the World Health Organization (WHO) (6) are all examples of recommendations and guidelines aimed at improving blood transfusion safety.

Additionally, especially since the 1990s, transfusion committees and hemovigilance programs began to be regulated and deployed, initially in France in 1993 and thereafter in England with the Serious Hazards of Transfusion (SHOT) initiative in 1996 $6^{(7)}$, which was extended to the Common Market with the institution of the European Hemovigilance Network. In Brazil, the National Hemovigilance scheme was implemented in 2002 with the objectives of collecting and processing information or unexpected adverse effects resulting from the transfusion of blood and also of preventing administrative errors (clerical errors such as typing, recording, conference mistakes, etc.). The latter, surprisingly, is more common than viral transmissions and often omitted by the services in Brazil and is not reported in the statistics ${ }^{(8)}$.

While the system of notification of transfusion reactions in the UK (SHOT) revealed that approximately $66.7 \%$ of transfusion reactions reported are related to errors in the identification of recipients ${ }^{(7)}$, a study conducted at the Department of Health of the State of New York determined that the risk management of wrong red blood cell (RBC) transfusions is one in every 14,000 transfusions performed and misclassification of ABO is 1 for every 38,000 transfusions ${ }^{(9)}$. Moreover, data from Bulletin No. 5 (2012) of the national agency of Sanitary surveillance in Brazil, ANVISA, reported 5340 transfusion reactions in the previous year with an estimated underreporting of $50.1 \%$, and only 24 acute immune hemolytic reactions. This number represents only 1 per 148,655 of the 3.57 million transfusions performed, demonstrating the high degree of underreporting ${ }^{(10)}$.

On the other hand, in recent years, much has been published about the cost-effectiveness of blood transfusions, especially in studies that have shown the close association between blood transfusions and poor clinical outcomes, including a prolonged stay in the intensive care and increased rates of nosocomial infections, multiorgan failure, and death ${ }^{(11)}$.

These studies have mainly addressed the inappropriate indications and few have examined excessively high transfusion rates. But where over-transfusion has been studied, levels of the order of 24 to $75 \%$ have been reported ${ }^{(12)}$. It has also been shown that blood transfusion rates between hospitals for similar surgical procedures, such as coronary artery bypass grafting, ranged from $7.8 \%$ to $92.8 \%{ }^{(11)}$.

A study conducted in Northern Ireland draws attention to the fact that in considering whether the use of a RBC transfusion is appropriate or not, consideration should be given not only to the issue of "whether" to transfuse, but also to "how much" to transfuse. The authors demonstrated that in this study $23 \%$ of transfusions were considered inappropriate and that $19 \%$ of patients were over-transfused ${ }^{(5)}$.

An observational study of transfused obstetric patients in two Dutch hospitals noted that of $311 \mathrm{RBC}$ units transfused to 90 patients, 143 units (46\%) were possibly inappropriate partly due to over-transfusion ${ }^{(13)}$. 
A North American study that assessed hemoglobin $(\mathrm{Hb})$ levels after transfusion found that the rate of over-transfusion, that is a $\mathrm{Hb}$ level at discharge greater than $10 \mathrm{~g} / \mathrm{dL}$ in patients after elective transfusions, was $27.8 \%{ }^{(6)}$.

A multicenter retrospective observational French study that evaluated the appropriateness of RBC transfusions showed that 93\% percent of pre-transfusions and $79 \%$ of hemoglobin concentrations at discharge were in agreement with the French national guidelines. The study concluded that the rate of inadequate indications of RBC was satisfactory, however, its use was excessive and the authors proposed that the maxim employed in transfusion medicine "transfuse the right product, to the right patient, at the right time" should be extended to include "at the right dose using the right skills ${ }^{(14)}$.

In Spain, when investigating the impact of three national blood transfusion indicators (NBTIs) specifically designed for critical care regarding the appropriate blood transfusion indications, researchers observed that the inappropriate use of concentrated hemoglobin $(\mathrm{CH})$, platelet concentrate and fresh frozen plasma was approximately $13 \%, 48 \%$ and $67 \%$, respectively. They then concluded that the introduction of NBTI guidelines demonstrated a variable impact on the appropriateness of blood component transfusions in critically ill patients ${ }^{(15)}$.

In contrast, other authors have demonstrated that the implementation of an evidence-based transfusion protocol in a surgical intensive care unit, together with continued reinforcement on the rationale for transfusion, led to a significant reduction in the number of infused RBC units and the number of patients transfused without an increase in mortality ${ }^{(16,17)}$.

A study performed at the Hospital de Clinicas de Porto Alegre (Brazil) to assess the appropriateness of requests for blood products in three sectors of the hospital based on its protocol on care routines for blood component transfusions, found that the clinical sector was the most efficient by requesting $85.57 \%$ of its transfusions satisfactorily, followed by the intensive care unit $(81.4 \%)$ and finally the surgical sector $(71.42 \%)$. Only $2.96 \%$ requests could not be assessed for not having enough information to decide on the conformity or otherwise of transfusion requests ${ }^{(18)}$.

In a study conducted in 226 blood centers of the nucleus of hemotherapy and transfusional agencies in 178 municipalities in the state of Minas Gerais, Brazil found that transfusion committees were present in $63.4 \%$ of the services visited. Transfusion incidents were reported by $53(36.8 \%)$ transfusion services with transfusion committees and by only eight $(9.6 \%)$ without transfusion committees with $543(97.5 \%)$ and $14(2.5 \%)$ notifications, respectively. The authors of this study concluded that, the incidence of notification and investigation of the causes of transfusion reactions was higher in transfusion services where a transfusion committee was present. However, despite these results, the performance of transfusion committees was found to be incipient and better organization and effectiveness are required ${ }^{(19)}$.

In the work of Souza et al. ${ }^{(20)}$ analyzing the justifications for transfusion of red blood cells, the authors noted that of 334 randomized transfused RBC units, for which just 77 (23.05\%) were in conditions to be evaluated, only 47 (61.04\%) units were correctly indicated. The authors concluded by emphasizing the importance of adopting a protocol to rigorously analyze transfusions, the application of blood bank awareness campaigns on the rational use of blood, and the implementation of strategies to use blood products more effectively. To the strategies proposed, we add the deployment and/ or activeness of transfusion committees, that have been mandatory in Brazil since $2004^{(21)}$, which would act in the monitoring and prevention of adverse effects of transfused blood products.

\section{References}

1. Ferreira O, Martinez EZ, Mota CA, Silva AM. Avaliação do conhecimento sobre hemoterapia e segurança transfusional de profissionais de enfermagem. Rev Bras Hematol Hemoter. 2007;29(2):160-7.

2. Brasil. Ministério da Saúde. Agência Nacional de Vigilância Sanitária. RDC N ${ }^{\circ} 57,16$ dezembro 2010. Determina o Regulamento Sanitário para Serviços que desenvolvem atividades relacionadas ao ciclo produtivo do sangue humano e componentes e procedimentos transfusionais [Internet]. Brasília: MS; 2010 [cited 2012 Jun 21]. Available from: http://bvsms. saude.gov.br/bvs/saudelegis/anvisa/2010/res0057_16_12_2010.html

3. Brasil. Ministério da Saúde. Portaria No 1.353, 13 junho 2011. Aprova o Regulamento Técnico de Procedimentos Hemoterápicos [Internet]. Brasília: MS; 2011. [cited 2012 Mar 21] Available from: http://bvsms. saude.gov.br/bvs/saudelegis/gm/2011/prt1353_13_06_2011.html

4. British Committee for Standards in Haematology. Guideline on the Administration of Blood Components [Internet]. London: British Committee for Standards in Haematology. [cited 2012 Nov 21]. Available from: http://www.bcshguidelines.com/documents/Admin_blood_ components_bcsh_05012010.pdf

5. Directive 2002/98/EC of the European Parliament and of the Council of 27 January 2003 setting standards of quality and safety for the collection, testing, processing, storage and distribution of human blood and blood components and amending Directive 2001/83/EC. Official Journal L 33, 08/02/2003, p. 30 - 40. London: The European Parliament and the Council of the European Union [cited 2011 Oct 2]. Available from: http:// www.ema.europa.eu/docs/en_GB/document_library/Regulatory_and_ procedural_guideline/2009/10/WC500004481.pdf

6. World Health Organization. Global Database on Blood Safety. Report 2004-2005. Geneva: WHO; 2005. [cited 2011 Aug 21]. Available from: http://www.who.int/bloodsafety/global_database/ GDBSReport2004-2005.pdf

7. Carneiro-Proietti AB, Simoes BJ, Fernandes MF, Souza ME, Delgado $\mathrm{RB}, \mathrm{Abib}$ AR. Haemovigilance in Brazil. Establishment and perspectives. Transfusion Today. 2005; 65:7-8.

8. Eder AF, Chambers LA. Noninfectious complications of blood transfusion. Arch Pathol Lab Med. 2007;131(5):708-18.

9. Agência Nacional de Vigilância Sanitaria. Boletim de Hemovigilância $\mathrm{n}^{\circ} 5$ [Internet]. Brasília: Ministério da Saúde; 2012 [cited 2013 Jan 3]. Available from: http://portal.anvisa.gov.br/wps/wcm/connect/ b38ebb004dc642d7861dbed6059e5711/boletim 5 atualizado. pdf?MOD=AJPERES

10. Edwards J, Morrison C, Mohiuddin M, Tchatalbachev V, Patel C, Schwickerath VL, et al. Patient blood transfusion management: discharge hemoglobin level as a surrogate marker for red blood cell utilization propriateness. Transfusion. 2012;52(11):2445-51.

11. Barr PJ, Donnelly M, Cardwell CR, Parker M, Morris K, Bailie KE. The appropriateness of red blood cell use and the extent of overtransfusion: right decision? Right amount? Transfusion. 2011;51(8):1684-94.

12. So-Osman C, Cicilia J, Brand A, Schipperus M, Berning B, Scherjon $\mathrm{S}$. Triggers and appropriateness of red blood cell transfusions in the postpartum patient: a retrospective audit. Vox Sang. 2010;98(1):65-9. Comment in: Vox Sang. 2010;98(4):579; author reply 580.

13. Gouëzec H, Berger E, Bergoin-Costello V, Betbèze V, Bourcier V, Damais 
A, Drouet N, Ducroz S, Fialon P, Hervé I, Huchet C, Lassale B, Léo S, Lovi V, Le Niger C, Moron S, Renom P, Delaunay C, Turmel V; Groupe des Hémobiologistes et Correspondants d'Hémovigilance. [Suitability of red blood cell transfusion: a multicenter study]. Transfus Clin Biol. 2010 Dec;17(5-6):318-30. French.

14. Leal-Noval SR, Arellano-Orden V, Maestre-Romero A, Muñoz-Gómez M, Fernández-Cisneros V, Ferrándiz-Millón C, et al. Impact of national transfusion indicators on appropriate blood. usage in critically ill patients. Transfusion. 2011;51(9):1957-65.

15. Brandt MM, Rubinfeld I, Jordan J, Trivedi D, Horst HM. Transfusion insurgence: practice change through education and evidence-based recommendations. Am J Surg 2009;197(3):279-83.

16. Brandt MM, Rubinfeld I, Jordan J, Trivedi D, Horst HM. Transfusion insurgence: practice change through education and evidence-based recommendations. Am J Surg 2009;197: 279-83.

17. Leal-Noval SR, Arellano-Orden V, Maestre-Romero A, Muñoz-Gómez M, Fernández-Cisneros V, Ferrándiz-Millón C, et al. Impact of national transfusion indicators on appropriate blood. usage in critically ill patients.
Transfusion. 2011;51(9):1957-65.

18. Sekine L, Wirth LF, Faulhaber GA, Seligman BG. Blood-based products request profile analysis in Hospital de Clínicas de Porto Alegre in 2005. Rev Bras Hematol Hemoter. 2008;30(3):202-7.

19. Carvalho RV, Brener S, Ferreira AM, Valle MC, Moraes-Souza H. Transfusion Practices Committee of a public blood bank network in Minas Gerais, Brazil. Rev Bras Hematol Hemoter. 2012;34(6):416-20.

20. Souza DA, Silva FG, Souza PJ. Critical evaluation of justifications for the transfusion of red blood cells: the reality of a government emergency hospital. Rev Bras Hematol Hemoter. 2013;35(4):263-67.

21. Agência Nacional de Vigilância Sanitária. RDC 153, de 14 de junho 2004. Determina o Regulamento Técnico para os procedimentos hemoterápicos, incluindo a coleta, o processamento, a testagem, armazenamento, o transporte, o controle de qualidade e o uso humano de sangue, e seus componentes, obtidos do sangue venoso, do cordão umbilical, da placenta e da medula óssea [Internet]. Brasília: Ministério da Saúde; 2004. [cited 2012 Jan 3]. Available in: http://portal.saude.gov. br/portal/arquivos/pdf/resolucao_153_2004.pdf 